\title{
Interleukin 27 Measurement
}

National Cancer Institute

\section{Source}

National Cancer Institute. Interleukin 27 Measurement. NCI Thesaurus. Code C74824.

The determination of the amount of interleukin 27 present in a sample. 